\title{
Pediatric Poisoning Trend in Lucknow District, India
}

\author{
Rathore $\mathrm{S}^{1}$, Verma $\mathrm{AK}^{2}$, Pandey $\mathrm{A}^{3}$ and Kumar $\mathrm{S}^{4}$
}

${ }^{1}$ Junior resident, Department of Forensic Medicine \& Toxicology, KGMU, Lucknow, India

${ }^{2}$ Associate Professor and Head, Department of Forensic Medicine \& Toxicology, KGMU, Lucknow, India

${ }^{3}$ Junior resident, Department of Forensic Medicine \& Toxicology, KGMU, Lucknow, India

${ }^{4}$ Phd scholar, Department of Pathology, KGMU, Lucknow, India

\begin{abstract}
Poisoning is a major problem in the pediatric population. The offending substances used vary from place to place. Although the clinical outcome of these exposures is usually favorable, deaths do occur. The present study was undertaken to determine in children the major offending agents, their seasonal distribution, mortality associated with them and change, if any in the type of poison by comparing data with previous studies available. This prospective study was carried out at King George Medical College and it's associated Gandhi smarak hospitals, Lucknow. A total of 100 pediatric patients of $<15$ years of age made the material of the following series. $62 \%$ were under 5 years of age and $70 \%$ male. Incidence was also more common in urban areas $(55 \%)$ as compared to rural (45\%) and rainy season was found to be the most vulnerable period for poisoning. Kerosene and snake bite were the most common offending agents, both accounting for $31 \%$ cases each. Mortality of $4 \%$ was reported. Mortality due to poisoning in children has remained high over the last five decades (2.9\%-4.7\%). Kerosene has remained the single largest contributor to childhood poisoning $(51.5 \%$ in the 1960 s vs. $52.8 \%$ in the 1990 s).
\end{abstract}

Keywords: Childhood; Poisoning; Seasonal trends

\section{Introduction}

Poisoning is a major problem in children all over the world. However the offending agent and the associated morbidity and mortality vary from place to place and change over a period of time. With the control of infectious diseases, the contribution of poisoning to childhood mortality and morbidity has been increasing in developed countries [1-6]. The developed world has accurate information on incidence and changing trends of causative agents as a result of rigorous population census and mortality data and the development of poisons control centres (PCC) [7-11]. In contrast, pediatric poisoning incidence in developing countries is poorly documented $[8,12,13]$. Likewise in India limited data are available on morbidity and mortality related to poisoning in children, in particular the changes in its pattern over the years. Many studies have been done relating to the age incidence; sex incidence; socio-economic status; seasonal distribution; type of poison consumed; mode of poisoning and outcome of cases.

The present study was undertaken to determine in children the major offending agents, their seasonal distribution, mortality associated with them and change, if any in the type of poison by comparing data with previous studies available.

\section{Material and Methods}

This prospective study was carried out at King George Medical College and its associated Gandhi Smarak hospitals, Lucknow over a period of 1 year from Jan 2011 to Dec 2011. All cases of toxin exposure or poisoning whether bites, household poisons, agricultural or medicinal compounds were included. Detailed case history was obtained from the attendant regarding the nature of poison, time of consumption, circumstances of poisoning and immediate symptoms.

\section{Result}

A total of 100 poisoning cases of $<15$ years of age were studied in the pediatric department of KGMU, Lucknow. $62 \%$ were under 5 years of age and $70 \%$ male (Table 1). Incidence was also more common in urban areas (55\%) as compared to rural (45\%) (Table 1) and rainy season was found to be the most vulnerable period for poisoning when $36 \%$ of the cases were reported (Table 2). Kerosene and snake bite were the most common offending agents, both accounting for $31 \%$ cases each (Table 2). Maximum number of kerosene poisoning cases was reported in summer while in rainy season cases of snake bite and organophosphorus poisoning were more common. Mortality of $4 \%$ was reported in this series and it was found to be maximum in snake bite cases followed by kerosene poisoning \& organophosphorus poisoning (Table 3).

\section{Discussion}

The childhood unintentional poisoning death rate has declined over the past decade, largely due to child resistant packaging, product reformulation, heightened parental awareness and appropriate interventions [14]. However children continue to be at significantly greater risk than adults for unintentional poisoning, because they are smaller, have faster metabolic rates and are less able to physically

\begin{tabular}{|c|c|c|c|}
\hline & MALE & FEMALE & \\
\hline \multirow[t]{2}{*}{$\begin{array}{c}\text { Age } \\
0-5 \\
5-10 \\
10-15\end{array}$} & $\begin{array}{l}45 \% \\
13 \% \\
12 \%\end{array}$ & $\begin{array}{l}17 \% \\
6 \% \\
7 \%\end{array}$ & \\
\hline & $70 \%$ & $30 \%$ & \\
\hline $\begin{array}{c}\text { Habitat } \\
\text { Rural } \\
\text { Urban }\end{array}$ & $\begin{array}{l}32 \% \\
38 \%\end{array}$ & $\begin{array}{l}13 \% \\
17 \%\end{array}$ & $\begin{array}{l}\text { Total } \\
45 \% \\
55 \%\end{array}$ \\
\hline
\end{tabular}

Table 1: Demographic characteristics.

*Corresponding author: Sachil Kumar, PhD scholar, Department of Pathology, KGMU, Lucknow, India, E-mail: sachilvohra@gmail.com

Received March 04, 2013; Accepted April 20, 2013; Published April 30, 2013

Citation: Rathore S, Verma AK, Pandey A, Kumar S (2013) Pediatric Poisoning Trend in Lucknow District, India. J Forensic Res 4: 179. doi:10.4172/2157 7145.1000179

Copyright: @ 2013 Rathore S, et al. This is an open-access article distributed unde the terms of the Creative Commons Attribution License, which permits unrestricted use, distribution, and reproduction in any medium, provided the original author and source are credited. 
Citation: Rathore S, Verma AK, Pandey A, Kumar S (2013) Pediatric Poisoning Trend in Lucknow District, India. J Forensic Res 4: 179. doi:10.4172/2157-7145.1000179

\begin{tabular}{|c|c|c|c|c|c|}
\hline & Spring & Summer & rainy & winter & Total \\
\hline Kerosene & 6 & 12 & 7 & 6 & $\mathbf{3 1}$ \\
\hline Snake bite & 1 & 12 & 14 & 4 & $\mathbf{3 1}$ \\
\hline Organophosphorus & 1 & 2 & 5 & 4 & $\mathbf{1 2}$ \\
\hline Others & 3 & 2 & 10 & 11 & $\mathbf{2 6}$ \\
\hline Total & $\mathbf{1 1}$ & $\mathbf{2 8}$ & $\mathbf{3 6}$ & $\mathbf{2 5}$ & $\mathbf{1 0 0}$ \\
\hline
\end{tabular}

Table 2: Type of Poison.

\begin{tabular}{|c|c|}
\hline Type of poison & Mortality \\
\hline Kerosene & 1 \\
\hline Snake bite & 2 \\
\hline Organophosphorus & 1 \\
\hline
\end{tabular}

Table 3: Mortality.

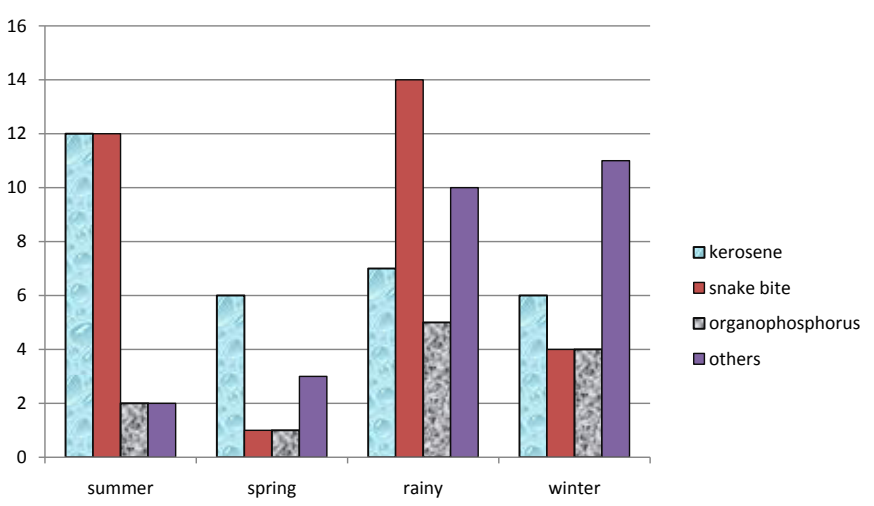

Figure 1: Seasonal Variation of Poisoning Cases.

handle toxic chemicals. In addition natural curiosity and their desire to put everything in their mouth increase their poisoning risks.

Present study observed that the most vulnerable age group for poisoning is under 5 years which is consistent with studies from Jordan [15]. In various studies from Kuwait [16], Bangladesh [17], and Colombo [18], 1-3 years was reported to be the most vulnerable age group to be affected. Hussein A Bataineh et al. [19] from Saudi Arabia \& Raymond Cripps et al from Australia observed that majority of children were under 5 years of age group.

There was a male preponderance in the present series which is concurrent from various other works $[17,18-21]$.

Present study observed predominance of poisoning in urban children which was in agreement with Manzar $\mathrm{N}$ et al. [22] study from Karachi. Also the incidence of poisoning was found to be highest in lower income group followed by lower middle income group which was in concordance with work in Karachi [22] (80\% lower income group, $19 \%$ middle income group and $1 \%$ fair income group). These observations can be attributed to higher availability of various poisons to urban children due to the more use of various chemical products in urban areas. While increased incidence in lower income group can be attributed to lower level of education, improper storage of chemicals \& household products and lower level of care towards the child.

In the present series, rainy season was the most vulnerable period when maximum no. of cases was reported followed by summer, winter and spring. This was in agreement with various other works [17,23,24]. This can be explained on the basis of more snakes coming out during rainy season due to filling of water in their burrows and thus increasing the human snake interaction resulting in more no. of snake bites during the season, while summer being a dry season, thirst causes an increased attraction towards liquids thus increasing cases of accidental poisoning especially Kerosene poisoning which was the commonest poisoning in present series. This was again consistent with various studies from Kuwait [16], Colombo [18] \& New Delhi [21]. This can be attributed to the use of kerosene oil as a fuel especially in lower income group, its storage in easily accessible places \& its colour which is often mistaken for soft drink.

$4 \%$ mortality was found in our series. Similar mortality incidence was reported from Lalitpur (UP), Nepal \& Oslo [25,26].

\section{Conclusion}

Poisoning is most common in $0-5$ years age group as far as pediatric poisoning is concerned; also it is more frequent in males of urban areas especially in lower income group. Rainy season is the most vulnerable period, when maximum no. of snake bites are reported while kerosene poisoning is the most frequently reported household poisoning. Around $4 \%$ cases prove to be fatal and snake bites are responsible for most of the poison related fatalities in children (Figure 1).

There is a need to establish regional toxicological centers which can help guide hospitals in the quick identification of poisons and provide guidelines for treatment. There is also a need to initiate public awareness campaigns to attempt to decrease morbidity and mortality from this eminently preventable problem.

\section{Ethical Approval}

Ethical approval taken from the university ethics committee.

\section{Acknowledgement}

We thanks to the Department of pediatrics and Forensic Medicine \& Toxicology of King George's Medical University, who facilitates our mission at the University.

\section{References}

1. Christoffel KK, Marcus D, Sagerman S, Bennett S (1988) Adolescent suicide and suicide attempts: a population study. Pediatr Emerg Care 4: 32-40.

2. Lewis HH, Cronje RE, Naude SP, van den Berg C (1989) Accidental poisoning in childhood. S Afr Med J 76: 429-431.

3. Pearn J, Nixon J, Ansford A, Corcoran A (1984) Accidental poisoning in childhood: five year urban population study with 15 year analysis of fatality. $\mathrm{Br}$ Med J (Clin Res Ed) 288: 44-46.

4. Litovitz TL, Flagler SL, Manoguerra AS, Veltri JC, Wright L (1989) Recurrent poisonings among paediatric poisoning victims. Med Toxicol Adverse Drug Exp 4: 381-386.

5. Wiseman HM, Guest K, Murray VSC, Volans GN (1987) Accidental poisoning in childhood: A multicentre survey I. General epidemiology. Hum Toxicol 6: 293-301.

6. Jacobsen D, Halvorsen K, Marstrander J, Sunde K, Bakken AF (1983) Acute poisonings of children in Oslo. A one year prospective study. Acta Paediatr Scand 72: 553-557.

7. Kivistö JE, Mattila VM, Arvola T, Paavola M, Parkkari J (2008) Secular trends in poisonings leading to hospital admission among Finnish children and adolescents between 1971 and 2005. J Pediatr 153: 820-824.

8. Meyer S, Eddleston M, Bailey B, Desel H, Gottschling S, et al. (2007) Unintentional household poisoning in children. Klin Padiatr 219: 254-270.

9. McKenzie LB, Ahir N, Stolz U, Nelson NG (2010) Household cleaning productrelated injuries treated in US emergency departments in 1990-2006. Pediatrics 126: 509-516.

10. Liebelt EL, DeAngelis CD (1999) Evolving trends and treatment advances in pediatric poisoning. JAMA 282: 1113-1115.

11. Litovitz T, Manoguerra A (1992) Comparison of pediatric poisoning hazards an analysis of 3.8 million exposure incidents. A report from the American Association of Poison Control Centers. Pediatrics 89: 999-1006. 
Citation: Rathore S, Verma AK, Pandey A, Kumar S (2013) Pediatric Poisoning Trend in Lucknow District, India. J Forensic Res 4: 179. doi:10.4172/2157-7145.1000179

12. Tagwireyi D, Ball DE, Nhachi CF (2002) Poisoning in Zimbabwe: a survey of eight major referral hospitals. J Appl Toxicol 22: 99-105.

13. Balme KH, Roberts JC, Glasstone M, Curling L, Rother HA, et al. (2010) Pesticide poisonings at a tertiary children's hospital in South Africa: an increasing problem. Clin Toxicol (Phila) 48: 928-934.

14. National SAFE KIDS Campaign (NSKC). Poisoning Fact Sheet. Washington (DC): NSKC, 2004

15. Shotar AM (2005) Drug poisoning in childhood. Saudi Med J 26: 1948-1950.

16. Akhtar S, Gulati R, Fahad Al Anezi (2006) Risk factors in acute poisoning in children-A retrospective study. Kuwait Medical Journal 38: 33-36.

17. Rashid AKM (2007) Seasonal variation of childhood acute poisoning. Pakistan Journal of Medical Science 23: 1-5.

18. Lucas GN (2006) A hospital based prospective study of acute childhood poisoning. Srilanka Journal of child health 35: 12-19.

19. Hussein AB, Ahmed AB (2007) Childhood accidental poisoning in Tafila. Iran J Ped 17: 23-27.
20. Hockey R, Reith D, Miles E (2000) Queensland injury surveillance unit childhood poisoning and ingestion, injury bulletin 60 : 1-6.

21. Gupta SK, Peshin SS, Srivastava A, Kaleekal T (2003) A study of childhood poisoning at National Poisons Information Centre, All India Institute of Medical Sciences, New Delhi. J Occup Health 45: 191-196.

22. Manzar N, Saad SM, Manzar B, Fatima SS (2010) The study of etiological and demographic characteristics of acute household accidental poisoning in children--a consecutive case series study from Pakistan. BMC Pediatr 10: 28.

23. Matiyahu L, Vladimir G (2000) Acute poisoning in children. IMAJ 2: 504-506.

24. Moghadamnia AA, Shirvani TE, Esmaeili MR, Bayat Z, Gholotabar ZM (2004) A report of childhood poisoning in Babol. Archives of Iranian medicine 7: 297-299

25. Ghai OP, Gupta P (2004) Poisonings and accidents. Ghai essential pediatrics (6th ed). CBS Publishers and distributers 640.

26. Jacobsen D, Halvorsen K, Marstrander J, Sunde K, Bakken AF (1983) Acute poisonings of children in Oslo. A one year prospective study. Acta Paediatr Scand 72: 553-557. 